\title{
Use of Trimethoprim to Obtain Thymine-requiring Mutants of Streptococcus faecalis
}

\author{
By M. H. E. ANDREW \\ City of Leicester Polytechnic, School of Pharmacy, Microbiology Unit, \\ P.O. Box I 43, Leicester, $L E$ I $9 B H$
}

(Received 24 April 1972; revised 24 August 1972)

INTRODUCTION

The use of a folic acid antagonist to isolate thymine-requiring (thy) mutants was first employed by Okada, Yanagisawa \& Ryan (1960) with Escherichia coli. Thy mutants arise when wild-type bacteria are grown in medium containing the drug (aminopterin or trimethoprim) and thymine (or thymidine). The mutants lack thymidylate synthetase (Barner \& Cohen, 1959) and are able to incorporate exogenous thymine (Crawford, I958) which gives them a selective advantage over the wild-type bacteria (Bertino \& Stacey, 1966; Wilson, Farmer \& Rothman, 1966). This is now an established technique which has also been used successfully with Salmonella typhimurium (Okada, Homma \& Sonohara, 1962), Bacillus megaterium (Wachsman, Kemp \& Hogg, 1964), Aerobacter aerogenes (Harrison, 1965) and B. subtilis (Farmer \& Rothman, 1965).

This report describes the isolation of thy mutants of Streptococcus faecalis by a modification of the trimethoprim technique of Stacey \& Simson (1965).

\section{METHODS}

Strains and growth conditions. Streptococ'us faecalis NCTC 775 (from the National Collection of Type Cultures) and $S$. faecalis $\mathrm{EB} / \mathrm{F} / 3 \mathrm{O} / 82$ (from P. H. A. Sneath) were grown in a chemically defined medium ( $\left.\mathrm{SF}_{35}\right)$ which was modified from media described by VanDemark (1950), McCoy \& Wender (1953), Stonehill \& Hutchison (1966) and Clark, Witter \& Ordal (1968).

Salts $A$ (made up as a 20-fold concentrated stock solution containing per 1 distilled water): $\mathrm{K}_{2} \mathrm{HPO}_{4}, \mathrm{I} 40 \mathrm{~g} ; \mathrm{KH}_{2} \mathrm{PO}_{4}, 50 \mathrm{~g}$; tri-sodium citrate, $50 \mathrm{~g}$; sodium acetate, $10 \mathrm{~g}$; $\left(\mathrm{NH}_{4}\right)_{2} \mathrm{SO}_{4}$, $20 \mathrm{~g}$; L-arginine, $2 \mathrm{~g}$; L-cysteine, $4 \mathrm{~g}$; L-glutamic acid, $8 \mathrm{~g}$; L-leucine, $2 \mathrm{~g}$; L-iso-leucine, $4 \mathrm{~g}$; L-lysine, $4 \mathrm{~g}$; L-serine, $2 \mathrm{~g}$; L-threonine, $2 \mathrm{~g}$; DL-valine, $2 \mathrm{~g}$; glycine, $\mathrm{I} \cdot 2 \mathrm{~g}$; L-histidine, $\mathrm{I} \cdot 2 \mathrm{~g}$; L-methionine, $\mathrm{I} \cdot 2 \mathrm{~g}$; L-phenylalanine, $800 \mathrm{mg}$; L-tryptophan, $800 \mathrm{mg}$; L-tyrosine, $400 \mathrm{mg}$; $\mathrm{MgSO}_{4} \cdot 7 \mathrm{H}_{2} \mathrm{O}, 250 \mathrm{mg}$.

Salts $B$ (made up as a roo-fold concentrated stock solution containing per $10.067 \mathrm{M}$ potassium phosphate buffer): thiamine $\mathrm{HCl}, 40 \mathrm{mg}$; calcium pantothenate, $40 \mathrm{mg}$; nicotinic acid, $40 \mathrm{mg}$; pyridoxal $\mathrm{HCl}, 40 \mathrm{mg}$; riboflavin-5-phosphoric acid, $100 \mathrm{mg}$; adenine sulphate, I g; guanine $\mathrm{HCl}, 2 \mathrm{~g}$; biotin, I mg; folic acid, $200 \mu \mathrm{g}$. Guanine $\mathrm{HCl}$ and riboflavin-5phosphoric acid caused precipitation when included in Salts B so they were made up separately, the guanine $\mathrm{HCl}$ being dissolved in hot acidified distilled water to make a roo-fold concentrate and the riboflavin in phosphate buffer as a 500-fold concentrate.

Salts $C$ (made up as a Ioo-fold concentrate stock solution containing per l distilled water): $\mathrm{MnSO}_{4} \cdot 4 \mathrm{H}_{2} \mathrm{O}, 2 \mathrm{~g} ; \mathrm{NaCl}, 2 \mathrm{~g} ; \mathrm{FeSO}_{4} \cdot 7 \mathrm{H}_{2} \mathrm{O}, 2 \mathrm{~g}$; tri-sodium citrate, $8 \mathrm{~g}$. When required thymine was made up as a 20 -fold concentrate by dissolving it in hot distilled water and the 
trimethoprim $\left(2,4\right.$-diamino-5- $\left(3^{\prime}, 4^{\prime}, 5^{\prime}\right.$-trimethoxybenzyl) pyrimidine $)$ as a 100 -fold concentrate in acidified distilled water.

All the solutions were sterilized by filtration through 0.8 and $0.2 \mu \mathrm{m}$ Gelman membrane filters (Hawkesley and Sons Ltd., Lancing, Sussex) with the exception of Salts A which was autoclaved at $10 \mathrm{lb} / \mathrm{in}^{2}$ for $10 \mathrm{~min}$. The stock solution of riboflavin was stored at room temperature $\left(20^{\circ} \mathrm{C}\right)$ to avoid precipitation, Salt solution A was stored at $-20^{\circ} \mathrm{C}$ to retard precipitation of sulphur-containing compounds, and the other solutions were stored in the dark at o to $4{ }^{\circ} \mathrm{C}$. The complete medium at $\mathrm{pH} 7$ was made up by adding the stock solutions to a glucose solution (final concentration $2 \%$ ). Solid medium included $\mathrm{I} \cdot 5 \%$ (w/v) Ionagar (Oxoid).

Single colonies from stock SF35 agar slopes were inoculated into $50 \mathrm{ml} \mathrm{SF} 35$ broth and incubated for $\mathrm{I} 5$ to $\mathrm{I} 8 \mathrm{~h}$ at $37^{\circ} \mathrm{C}$. The bacteria were then harvested by centrifugation, washed twice in phosphate buffer and finally resuspended in $10 \mathrm{ml}$ of the same buffer. The resulting bacterial suspension was used in the experiments as a $\mathrm{I} \%(\mathrm{v} / \mathrm{v})$ inoculum.

Growth measurements. Viable counts were made by diluting the bacteria in $0.067 \mathrm{M}$ phosphate buffer and either inoculating $0.1 \mathrm{ml}$ of an appropriate dilution on to $10 \mathrm{ml} \mathrm{SF}_{35}$ agar plates which had been overdried for $2 \mathrm{~h}$ at $37^{\circ} \mathrm{C}$ or by making pour plates using I ml of a dilution in $10 \mathrm{ml} \mathrm{SF} 35$ agar at $50^{\circ} \mathrm{C}$. Colonies were counted after $48 \mathrm{~h}$ incubation at $37^{\circ} \mathrm{C}$.

Extinction measurements were made at $553 \mathrm{~nm}$ with a Vitatron colorimeter (Fisons Scientific Apparatus Ltd, Loughborough, Leicestershire) using the riboflavin stock solution diluted to its working strength in distilled water as the blank.

\section{RESULTS}

When these strains of Streptococcus faecalis were incubated with $10 \mu \mathrm{g}$ trimethoprim $/ \mathrm{ml}$ and $50 \mu \mathrm{g}$ thymine/ml growth occurred almost immediately, without the customary 2- to 3-day lag, maximim turbidity was reached after io $\mathrm{h}$ and no mutants were detectable among approximately 5000 colonies screened for thymine dependence by replica plating. In the absence of thymine the bacteria were sensitive to trimethoprim losing viability after $2 \mathrm{~h}$ (Fig. I). Wild-type bacteria were therefore able to utilize exogenous thymine to reverse trimethoprim inhibition and selection of thy mutants was prevented.

The presence of adenine and guanine in the medium decreases the inhibitory effect of trimethoprim (Miovic \& Pizer, 1971) and, since these Streptococcus faecalis strains could grow without them, they were removed from the medium and the selection procedure repeated. Thymine was then unable to reverse trimethoprim inhibition but there was no increase in viable count even after 7 days. Thus the purines were obviously required in trimethoprim-containing medium before bacteria of any genotype would grow and yet added thymine allowed $\mathrm{Thy}^{+}$bacteria to overcome trimethoprim inhibition and grow almost normally preventing the selection of thy mutants.

To examine whether wild-type bacteria could still overcome trimethoprim inhibition with thymine after prior treatment with the drug alone, Thy ${ }^{+}$strains were incubated in complete medium with so $\mu \mathrm{g}$ trimethoprim $/ \mathrm{ml}$ for $9 \mathrm{~h}$ until the viable count and extinction remained constant (arrow, Fig. 1). At this point a portion of the culture was inoculated into fresh medium containing both the drug and $50 \mu \mathrm{g}$ thymine $/ \mathrm{ml}$. After a further two days of incubation a fully turbid culture was obtained and replica plating of colonies from surviving bacteria showed that $3 \mathrm{I} \%$ were thy mutants. They had a low thymine requirement $(2 \mu \mathrm{g} / \mathrm{ml})$ and produced easily recognizable colonies on $\mathrm{SF}_{35}$ agar replica plates which were smaller 


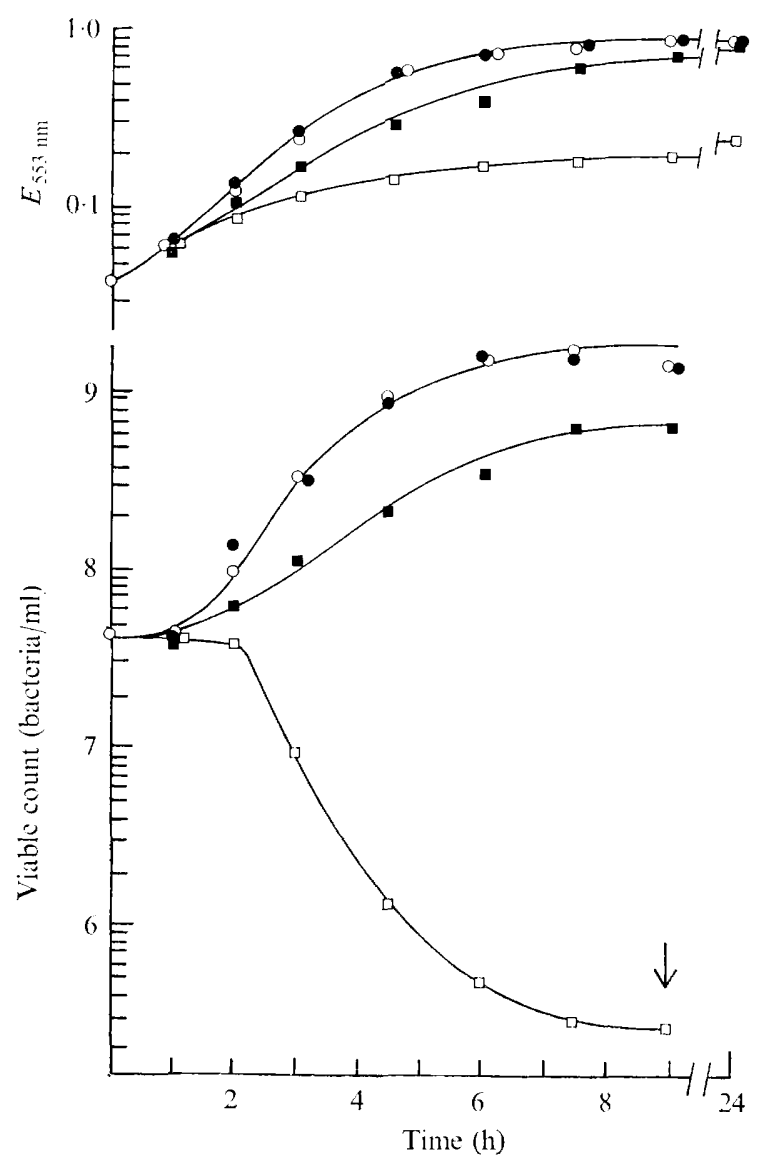

Fig. I. Growth of Streptococcus faecalis $\mathrm{EB} / \mathrm{F} / 30 / 82$ at $37^{\circ} \mathrm{C}$ in $\mathrm{SF} 35$ broth $\left(-\mathrm{O}_{-} \mathrm{O}-\right)$ or $\mathrm{SF} 35$ broth containing $50 \mu \mathrm{g}$ thymine $/ \mathrm{ml} \mathrm{(-O-O})$; Io $\mu \mathrm{g}$ trimethoprim $/ \mathrm{ml}(-\square-\square-)$; 10 $\mu \mathrm{g}$ trimethoprim $/ \mathrm{ml}$ and $50 \mu \mathrm{g}$ thymine/ml (- $-\mathbf{-}_{-}$). Viable counts were made by the pour plate technique.

than normal and semitransparent. These thy bacteria were resistant to trimethoprim which is characteristic of mutants selected in this way (Stacey \& Simson, 1965). Mutants arose whether or not trimethoprim was present during the second period of incubation which may indicate its persistence in the bacteria; however no growth occurred if thymine was absent.

It was tempting to infer that the viable bacteria surviving trimethoprim treatment (about $0.5 \%$ of the original population) contained thy mutants resistant to the drug. However, as found by Okada et al. (1960, I96I), no such mutants could be isolated from approximately 5000 colonies derived from this fraction. These bacteria therefore appear to need an initial treatment with trimethoprim before thy mutants have a selective advantage over wild-type cells during subsequent growth with thymine.

\section{DISCUSSION}

These wild-type strains of Streptococcus faecalis are unusual in that they were able to utilize exogenous thymine and thus overcome trimethoprim inhibition. This may be due to active deoxyribonucleotide catabolism in these strains which is usually absent in wild-type 
bacteria and prevents utilization of exogenous thymine (Beacham, Barth \& Pritchard, I968; Beacham \& Prichard, 1971). An alternative explanation may lie in the use of a complex growth medium for these streptococci which have fastidious nutritional requirements. Koch \& Burchall (197I) reported that Escherichia coli B could overcome trimethoprim inhibition with exogenous thymidine when grown in a complex medium containing amino acids, ribosides and vitamins.

A second unusual feature of these streptococci is that they gave rise to mutants with a low thymine requirement after trimethoprim selection. Usually mutants selected in this way have a high requirement for thymine ( $>20 \mu \mathrm{g} / \mathrm{ml}$ ) (Stacey \& Simson, I965; Okada, I966). The low requirement is considered to be the result of a second mutation at a locus unrelated to thy (Alikhanian, et al. 1966; Eisenstark, Eisenstark \& Cunningham, 1968) and a second selection procedure is needed (Harrison, 1965) to obtain these double mutants which have no phosphodeoxyribomutase or deoxyriboaldolase activity (Munch-Petersen, 1968). This lessens competition for deoxyribose-I-phosphate in the cell and lower concentrations of exogenous thymine suffice (Beacham et al. 1968; O’Donovan \& Neuhard, 1970). However the large numbers of thy mutants of Streptococcus faecalis arising after trimethoprim treatment does not accord with the selection of double mutants.

I am grateful to the Wellcome Foundation for their gift of trimethoprim and to Dr I. ab I. Davies for his very helpful discussion.

\section{REFERENCES}

Alikhanian, S. I., Iljina, T. S., Kaltiaeva, E. S., Kameneva, S. V. \& Sukhodolec, V. V. (1966). A genetical study of thymineless mutants of E. coli Kı2. Genetical Research 8, 83-100.

BARNER, H. \& Cohen, S. S. (1959). Virus-induced aquisition of metabolic function. IV. Thymidylate synthetase in thymine-requiring Escherichia coli infected by $\mathrm{T}_{2}$ and $\mathrm{T} 5$ bacteriophages. Journal of Biological Chemistry 234, 2987-299r.

Beacham, I. R., Barth, P. T. \& Pritchard, R. H. (I968). Constitutivity of thymidine phosphorylase in deoxyriboaldolase negative strains: dependence on thymine requirement and concentration. Biochimica et biophysica acta $\mathbf{1 6 6 , 5 8 9 - 5 9 2 .}$

Beacham, I. R. \& Pritchard, R. H. (1971). The role of nucleoside phosphorylases in the degradation of deoxyribonucleosides by thymine-requiring mutants of E. coli. Molecular and General Genetics IIo, 289-298.

Bertino, J. B. \& Stacey, K. A. (1966). Suggested mechanism for the selective procedure for isolating thymine-requiring mutants of Escherichia coli. Biochemical Journal ror, 326-336.

Clark, C. W., WitTer, L. D. \& Ordal, Z. J. (1968). Thermal injury and recovery of Streptococcus faecalis. Applied Microbiology 16, 1764-I 769.

CraWford, L. V. (1958). Thymine metabolism in strains of Escherichia coli. Biochimica et biophysica acta 30, $428-429$.

Eisenstark, A., Eisenstark, R. \& Cunningham, S. (1968). Genetic analysis of thymineless (thy) mutants in Salmonella typhimurium. Genetics 58, 493-506.

FARmer, J. L. \& Rothman, F. (1965). Transformable thymine-requiring mutant of Bacillus subtilis. Journal of Bacteriology 89, 262-263.

HARrison, A. P. (1965). Thymine incorporation and metabolism by various classes of thymine-less bacteria. Journal of General Microbiology 4r, 32 i-334.

Koch, A. E. \& Burchall, J. J. (I97I). Reversal of the antimicrobial activity of trimethoprim by thymidine in commercially prepared media. Applied Microbiology 22, 812-817.

McCoY, T. A. \& Wender, S. H. (1953). Some factors affecting the nutritional requirements of Streptococcus faecalis. Journal of Bacteriology 65, 660-665.

Miovic, M. \& PIzer, L. I. (197I). Effect of trimethoprim on macromolecular synthesis in Escherichia coli. Journal of Bacteriology 106, 856-862.

Munch-Petersen, A. (1968). Thymineless mutants of Escherichia coli with deficiencies in deoxyribomutase and deox yriboaldolase. Biochemica et biophysica acta $\mathbf{1 6 1}, 279-282$. 
O’Donovan, G. A. \& Neuhard, J. (1970). Pyrimidine metabolism in microorganisms. Bacteriological Reviews 43, 278-343.

OKaDA, T. (1966). Mutational site of the gene controlling quantitative thymine requirement in Escherichia coli $\mathrm{K}-\mathrm{I} 2$. Genetics 54, I 329-1 336.

OKada, T., Homma, J. \& Sonohara, H. (1962). Improved method for obtaining thymineless mutants of Escherichia coli and Salmonella typhimurium. Journal of Bacteriology 84, 602-603.

Okada, T., Yanagisawa, K. \& Ryan, F. J. (1960). Elective production of thymineless mutants. Nature, London 188, 340-34I.

Okada, T., YanagisaWA, K. \& Ryan, F. J. (1961). A method for securing thymineless mutants from strains of E. coli. Zeitschrift für vererbungslehre 92, 403-412.

STACEY, K. A. \& Simson, E. (I965). Improved method for the isolation of thymine-requiring mutants of Escherichia coli. Journal of Bacteriology 90, 554-555.

Stonehill, E. H. \& Hutchison, D. J. (1966). Chromosomal mapping by means of mutational induction in synchronous populations of Streptococcus faecalis. Journal of Bacteriology 92, 136-143.

VANDEMARK, P. J. (1950). The vitamin requirements for glycerol oxidation by Streptococcus faecalis. Journal of Bacteriology 59, 533-539.

WaChSman, J. L., Kemp, S. \& HoGG, L. (1964). Thymineless death in Bacillus megaterium. Journal of Bacteriology 87, 1079-1086.

Wilson, M. C., Farmer, J. L. \& Rothman, F. (1966). Thymidylate synthesis and aminopterin resistance in Bacillus subtilis. Journal of Bacteriology 92, 186-196. 